\title{
Development of a Discrete Choice Experiment (DCE) questionnaire to elicit values by pregnant women and decision-makers for the expansion of a NIPS- based prenatal screening program
}

Hung Manh Nguyen

Université Laval https://orcid.org/0000-0001-5325-8329

Carmen Lindsay

Centre de recherche du CHU de Quebec-Universite Laval

Mohammad Baradaran

Universite Laval

Jason Robert Guertin

Universite Laval Faculte de medecine

Leon Nshimyumukiza

Universite Laval Faculte de medecine

Bounhome Soukkhaphone

Universite Laval

Daniel Reinharz ( $\square$ Daniel.Reinharz@fmed.ulaval.ca)

Université Laval (Canada) https://orcid.org/0000-0003-4433-059X

\section{Research}

Keywords: Decision-makers, Discrete choice experiment, Health technology assessment, Non-invasive prenatal testing, Pregnant women, Policymaking

Posted Date: November 22nd, 2021

DOI: https://doi.org/10.21203/rs.3.rs-1087750/v1

License: (a) This work is licensed under a Creative Commons Attribution 4.0 International License.

Read Full License 


\section{Abstract}

\section{Background}

In an accountable world, being able to take into account the value given by relevant stakeholders to an intervention that could be offered to the population is considered as desirable. DCE is an approach particularly suited for the measurement of such values in the field of prenatal care. Yet, DCE studies in the field of prenatal screening have focused mainly on pregnant women and their care providers but have neglected another key actor, the decision-makers. The objective of the study was to develop a DCE instrument applicable to pregnant women and decision-makers, for the evaluation of new conditions to be added to a screening program for fetal chromosomal anomalies.

\section{Methods}

An instrument development study was undertaken. Methods employed included a literature review, a qualitative study performed on pregnant women and decision-makers, and a pilot project to validate the developed instrument and test the feasibility of its administration through an online survey platform.

\section{Results}

An initial list of ten attributes and levels were built from the information provided by the literature review and the qualitative research component of the study. Seven attributes were built based on responses provided by participants from both groups. Two attributes were built from what was said by women only and one from what was said by decision-makers only. Search for consensus through consultations and a focus group discussion led to the retention of eight attributes. A pilot project was then performed with 33 pregnant women. This led to the exclusion of one attribute that showed poor influence on the choice making. The final version of the instrument contains seven attributes.

\section{Conclusion}

This paper presents the construction of a DCE instrument that can be administered to pregnant women on the demand side, and decision-makers on the supply side. Such an instrument to measure the social desirability of an intervention could be an added value to the decision-making process of Health Technology Assessment agencies.

\section{Introduction}

Allowing stakeholders such as the population to influence, directly or indirectly, policy decisions is a fundamental component of democratic jurisdictions (1). In the health care sector, this influence is generally referred to by the terms 'participation', 'involvement' or sometimes 'engagement' (2). They cover the multiple modalities that allow different stakeholder groups to bring their input into the decisionmaking process on what services to provide to the population (3). 
Health economic evaluations (HEE) are a methodological approach that allows putting a judgement on the economic value of a health intervention (4). A lot of efforts have been deployed to allow some participation of the public in the HEE process (5-7). This has led to two approaches that include inputs from either patients or the general population, in the estimation of a benefit of having access to a health intervention: cost-benefit analyses (CBA) (via the use of willingness-to-pay and willingness-to-accept analyses) and cost-utility analyses (CUA) (8). Willingness-to-pay (WTP) analyses estimate health benefits as a monetary value whose importance reflects the value given by the respondents to a survey, for the evaluated intervention. Validity and ethical issues make this approach difficult to apply (9). It is therefore seldom used. The second approach, named cost-utility analyses (CUA), uses an indicator, qualityadjusted life-years (QALYs), to express the benefit of an intervention. QALYs quantify health outcome provided by an intervention in terms of gain in length of life adjusted by its patients or general populationdefined utility score or desirability $(10,11)$.

A key issue faced by these approaches is related to the fact that different groups of the population might value an intervention or the health produced by the intervention differently (12)(13). Although CBA and CUA could take into consideration inputs of different groups of the population, they commonly focus on only one group, usually the beneficiaries of the intervention under evaluation $(13,14)$. Researchers who use these approaches seldom consider other groups, like experts who are members of Health Technology Assessment (HTA) agencies committees and who make final recommendations to policymakers about the adoption of a technology. These experts can value the technology differently compared to the population, based on considerations, which are also socially relevant. This observation mainly comes from the fact that the WTP and utility instruments are built to express the value given to an intervention by its potential or effective beneficiaries (8).

The issue of participation has become even more complicated in the field of prenatal screening for fetal conditions by the fact that utilities cannot be estimated by the fetus (15). Mother's utilities can be used instead, but this would contravene with the habit to consider utilities of the main beneficiary of an intervention.

Thus, seeking for an alternative modality facilitating this participation becomes more desirable in the field of evaluation of prenatal screening programs, as major advances in prenatal screening and diagnosis technology leads to difficult decisions regarding which services to offer to the population. A relatively new blood test, namely non-invasive prenatal screening (NIPS) test, allows to measure analyzing cell-free fetal DNA (cfDNA) in maternal blood. It allows detecting a huge array of chromosomal anomalies (16), besides anomalies currently detected, which tend to be limited to trisomy 21 (Down syndrome), trisomy 13 (Patau syndrome) and trisomy 18 (Edward's syndrome). Decisions regarding which conditions could be added to a public program have to take into consideration, not only the uncertainty of test performance in detecting these new conditions, but also some key ethical, social and economic consequences for the society $(17,18)$. Very few studies have been done to estimate the expected cost-benefit of expanding the scope of NIPS beyond its use to detect the most common anomalies (i.e., trisomy 21, 18 and 13). For these reasons, there is, in the world of economic evaluation of 
prenatal testing, an interest to have methodological approaches that could overcome the limitation of CUA.

A discrete choice experiment (DCE) is a method used to explore the relative importance of different attributes within a decision-making process (19). DCE allows measuring a perinatal intervention that concerns a fetus or a newborn from the adult perspective, solving the problem of the impossibility to define utility values for a fetus $(20,21)$. A DCE instrument could also reflect the desirability of a perinatal intervention from the perspective of the population/patients and of other groups, as decision-makers or those who work in HTA agencies. It is on the last aspect particularly that this work is focused on.

This paper reports the development of a DCE instrument to measure the preferences of pregnant women and decision-makers for the expansion of the NIPS test for the detection of fetal chromosomal anomalies in a public prenatal screening program.

\section{Methodology}

The development of the DCE questionnaire was undertaken in sequential steps (Fig.1) based on best practice guidance $(19,22-24)$. The methods and approach for analysis for each stage are summarized in the following sections.

\section{Stage 1: Attribute Development}

Attribute development consisted of two distinct steps: (1) attribute identification; (2) attribute selection and framing.

\section{- Attribute identification}

The process of attribute identification started with a review of literature followed by in-depth interviews with pregnant women and decision-makers.

A systematic review of literature conducted by two researchers (HMN, BS) on the use of DCE in the field of prenatal screening for chromosomal anomalies was performed. The search strategy was validated by a librarian. Data extracted on the identification of attributes and levels for preferences of prenatal screening are presented in additional file 1 (full-unpublished report is available on request). The review led to identifying potential attributes that have been found to influence preferences to undertake a screening test for a new condition in a NIPS-based prenatal screening program.

A qualitative study was then undertaken to test the attributes suggested from the literature and identify others that would be regarded by both groups, the group of pregnant women and the group of decisionmakers, as important to consider in the decision-making process regarding the content of a public prenatal screening program. 
Semi-structured interviews, based on an interview guide (see additional file 2), were conducted with pregnant women $(n=12)$ and decision-makers $(n=4)$. This guide had been beforehand pretested with two pregnant women and one decision maker. These three persons were not included into the sample for this project. They were only asked to comment on the understanding of the interview guide.

Inclusion criteria for pregnant women were to be primigravida, aged 18 years or above, and being consulting at the obstetric department of the CHUL hospital in Quebec City (Canada) for a first prenatal echography. Inclusion criteria for decision-makers were to be either member of a permanent scientific committees of the Quebec's HTA Agency, INESSS (Institut National d'Excellence en Santé et Services Sociaux), or a public servant at the Ministry of Health and Social Service (Québec), and to be involved in decision-making processes on services to be provided to mothers and children.

All interviews were digitally recorded. The verbatim were transcribed by using NVivo Transcription (QRS International 2020). The transcriptions were independently checked by two researchers (HMN, CL) while relistening to the recordings.

The analysis was independently performed by these two researchers (HMN, $C L)$. It aimed at identifying key attributes and their levels. The initial framework used to guide the identification of the attributes was based on the interview guide (deductive approach) $(25,26)$. Additional codes were generated where required (inductive approach) $(25,26)$.

The analysis started with five pre-established dimensions that were expected to come out from the interviews: 1) monthly family expenses associated with a child's disability; 2) prevalence of a new disease added to the list of diseases searched for by NIPS; 3 ) performance of the test for this new disease, i.e., probability of identifying a child with a disability; 4) probability that a child tested positive has a severe phenotype; 5) out-of-pocket cost associated with being tested. New dimensions suggested by the interviews were added. Interviews were built in such a way that, at the beginning of the interview, respondents were incited to say whatever they thought was an important characteristic to consider when deciding which condition to screen for, without being interrupted or influenced.

The analysis was first based on triangulation (i.e., categories and themes have to be derived from several sources of information) (27). Moreover, all interviews were coded independently by the two researchers. In case of disagreement, discussions were held until a consensus on the final coding was reached.

Attributes identified by the two groups of respondents were merged. All possible levels arising from the interview were retained. Attributes defined by only one group were also included in the list of attributes/levels for the following selection procedure.

\section{- Attribute selection and framing}

Attribute selection followed an iterative process aiming at finding a consensus between both groups of participants, on a set of attributes to be included in the DCE questionnaire. The iterative approach was 
based on consultations and a focus group discussion. Discussions were held between research team members after each step to refine the list of attributes/levels.

Firstly, the consultation process was undertaken with the same participants who had participated in the attribute identification step and had accepted to be contacted for future study. A list of potential attributes and levels retrieved from the previous codification procedure was presented to the participants. This consultation process aimed to refine the first list of potential attributes and levels. This list was sent to each participant via e-mail, to explore their opinion regarding the dimensions' meaning and relevance. Participants were also asked to provide justification in case they considered one of the attributes to be irrelevant. Attributes that were considered relevant by the participants were thus retained and modified if needed, while those considered irrelevant were excluded.

At the second step, the list of retained attributes was refined based on a focus group discussion conducted with three pregnant women and one decision-maker solicited from the same hospital (focus group discussion with decision-makers alone were not held due to the limited pool of potential participants). They were asked to give their opinion on the relevance of attributes and levels.

Information gained from the attribute-selection process was synthesized by one researcher (MHN). The content of attributes and levels was then revised by the research team members to ensure their relevance and the comprehension of the wording.

Eight key attributes and their levels were identified.

\section{Stage 2: Experimental design and construction of tasks}

DCE design and construction of tasks followed the 10-points checklist best practice guidance for conjoint experiment design proposed by the International Society for Pharmacoeconomics and Outcomes Research (ISPOR) (22).

\section{- Construction of choice tasks}

An experimental design was performed in order to generate unforced choice questionnaires (28). The questionnaires consist of a series of two options that differ by their level at each of the questionnaire's dimensions (i.e., attributes). The attributes represent characteristics of a hypothetical additional test that could be added to the list of tests already included in a public prenatal screening program. Respondents must choose the preferred option or declare that they cannot decide which of the two options is the preferred one.

\section{- Experiment design}

The number of possible combinations (so-called alternatives) is determined by the number of attributes and levels. This experiment setup involved eight attributes (five attributes with two levels; three attributes with three levels), for a total of $2^{5} \times 3^{3}=864$ screening combinations in the full factorial design (29). 
Since this number was too high, we built a fractional factorial design using efficient design (instead of orthogonal design due to its limitations of interaction effect estimations), to reduce the sample of scenarios to a manageable level, while still being able to evaluate the effect of each attribute and their 2way interactions $(28,30)$. The design allowed defining the scenario based on orthogonality (no option dominates another), level balance (all levels of each attribute have an equal frequency), and minimum overlap (there is no overlap in attribute levels) $(22,28,30)$.

\section{Design of the questionnaire}

Generic labels were used to identify the options, called test A and test B across all the choice sets, because they do not reflect exact screening options and there was a possibility that labels might encourage the use of a heuristic approach (31). An opt-out option (no preference for option A or B) was added although there is risk that an opt-out option could lead to high levels of non-response where a trade-off is judged to be difficult (32). Test A and B were constructed in such a way that trade-offs were expected.

Questionnaires are built in such a way that pregnant women are asked which prenatal test they would prefer to have, whereas decision-makers are asked which prenatal test they would prefer to offer to pregnant women.

\section{Stage 3: DCE survey design}

Survey components include an introduction to the survey and explanation on its purpose, consent form, an explanation of attributes and levels, an example of DCE choice task followed by the eight/seven DCE choice tasks (for pregnant women and decision-makers, respectively), and questions on demographic data (age, sex (for decision-makers only), income) and on experience of having or knowing a child with disability.

The DCE questionnaires were transferred on Université Laval's (Canada) LimeSurvey platform (version 3.23.6+200929; https://www.questionnaires.cstip.ulaval.ca/).

\section{Stage 4: Pilot testing the DCE Survey.}

A pilot project was undertaken to explore the feasibility of the survey that will be administered to a large sample of respondents (i.e., explore the understanding of the tasks, the complexity of the choices, the time needed to fill the questionnaire), as well as the statistical relevance of the dimensions and levels of the first version of the final questionnaire. For practical reasons (a limited pool of potential respondents in the group of decision-makers), we could only test the questionnaires through this pilot project with pregnant women.

The pilot project was also used to elicit a dominant choice that will be added in the full-scale study with pregnant women and decision-makers. 


\section{- Sampling and recruitment}

A D-optimal design (33-35) was constructed by judiciously selecting 22 screening combinations, and thus conducted to a pairwise-DCE pilot project ( 2 by 2 scenarios per choice task) of $C(22,2)=231$ pairs. This project was undertaken using 33 individuals who were asked to give their opinion on 7 different choice tasks $\left(33^{*} 7=231\right)$. Detail on sample's calculation of this pilot project can be found in the additional file 3.

Participants had to be at a gestation age between 28 and 30 weeks. They were recruited among participants to a clinical trial (PEGASUS-2, ClinicalTrials.gov Identifier: NCT03831256) who had accepted to be solicited to participate in an additional study. In this stage, participants were asked to choose the screening option that either suits them the best in each of the tasks or state that they could not express a preference.

\section{- Data collection and analysis}

Choices in the DCE choice task were collected automatically by the LimeSurvey platform. Eligible participants received an invitation message containing information regarding the nature of the study, and a link that led them to participate in the study. Once the informed consent form was given by clicking on the "accept" function, participants had access to the DCE survey.

Participants were given two weeks to answer the survey. After two weeks, the link to the non-answered questionnaire was inactivated and sent to new solicited participants until the sample size had been reached.

The preference data were codified on Excel for analysis using a conditional logit model (SAS the LOGISTIC procedure, release 9.4) to estimate the effects of each attribute on the preference of the participants. The significance level was fixed at $0.25 \%(36)$.

\section{Results}

\section{Stage 1: Attribute Development}

Attribute identification methods resulted in the identification of ten categories that could potentially become attributes of a test that should influence, according to the respondents, the decision to expand the list of conditions screened for in a NIPS-based prenatal screening program. Each category contained multiple decisional points suggesting potential levels for each attribute. The source of each category is provided in Table 1. This step showed that pregnant women and decision-makers have many common preoccupations besides specific ones. 
Table 1

Decisional points to inform potential attributes with an indication of the sources

\section{Category}

(1) Conditions being screened

(2) Information from the test

(3) Test performance

(4) Test procedure

(5) Cost associated with the test

(6) Test uncertainty implication

(7) Acceptance of uncertainty level related to physical and intellectual problems

(8) Geographical assess to the test

(9) Moment in gestational age to obtain test result
Decisional points

Sources

Conditions that women are interested to know

Detect as many as possible conditions

Detecting severe conditions/anomalies

The diseases can be confirmed

Conditions that could also be screened at newborns

Reliable and comprehensive information

Easy to interpret the results

DM

Simple information

PW

Low false positive (less than 5\%) and false negative rates

Accept higher false positive rate

DM

Take the test regardless detection rate to reduce risk of any possible problems to the baby

Simple and rapid

DM

Women' stress

DM

Reasonable cost accepted by women

DM

At a reasonable cost

PW

Publicly funded tests

DM

Women stress/anxiety and public system cost $\quad$ DM

Difficult to make confirmation and prognosis DM

Not accept low level of certainty

PW, DM

Depend on individuals

DM

Test can be accessible in the proximity, either hospitals or clinics

As soon as possible

PW

8 - 10 weeks

PW 


\begin{tabular}{|lll|}
\hline Category & Decisional points & Sources \\
\hline (PW-pregnant women; DM-decision-makers) & $\mathrm{PW}$ \\
\hline
\end{tabular}

Indeed, several preoccupations were shared by both groups, notably regarding the likely need to select which conditions in the list of chromosomal anomalies that can be screened for by NIPS, the type of information resulting from the test that should be transmitted to parents, the test performance, the parent's out-of-pocket costs related to the test, and the level of certainty of the test result. Preoccupations regarding these categories could differ between pregnant women and decision-makers. For example, pregnant women desired to avoid excluding conditions, while decision-makers were concerned with limiting the choice to conditions whose disability can be prevented or mitigated thanks to a medical intervention. Sensibility and specificity (false negative rate and false positive rate) issues were raised by all four decision-makers, but not by pregnant women. Decision-makers, unlike women, did not raise the question of gestational age to receive the result of the test, and the question of 'geographical access to the test'. They tended to place greater emphasis on the complexity of the test procedure and discussed the issue of stress that the test might cause to women. Details are provided in Table 2. 
Table 2

List of potential attribute and levels

\begin{tabular}{|c|c|c|c|c|c|}
\hline \multicolumn{2}{|c|}{ Pregnant Women } & \multicolumn{2}{|c|}{ Decision-Makers } & \multicolumn{2}{|l|}{ Consensus } \\
\hline Attributes & Levels & Attributes & Levels & Attributes & Levels \\
\hline \multirow[t]{3}{*}{$\begin{array}{l}\text { Conditions } \\
\text { to be } \\
\text { screened }\end{array}$} & \multirow{2}{*}{$\begin{array}{l}\text { 1. Detect as } \\
\text { many as } \\
\text { possible } \\
\text { conditions }\end{array}$} & \multirow[t]{3}{*}{$\begin{array}{l}\text { Conditions } \\
\text { to be } \\
\text { screened }\end{array}$} & \multirow{2}{*}{$\begin{array}{l}\text { 1. Conditions } \\
\text { that women are } \\
\text { interested to } \\
\text { know }\end{array}$} & \multirow[t]{3}{*}{$\begin{array}{l}\text { Condition to } \\
\text { be screened }\end{array}$} & $\begin{array}{l}\text { 1.as many } \\
\text { as possible }\end{array}$ \\
\hline & & & & & $\begin{array}{l}\text { 2. non-rare } \\
\text { diseases }\end{array}$ \\
\hline & $\begin{array}{l}\text { 2. High } \\
\text { prevalent } \\
\text { genetic } \\
\text { conditions (not } \\
\text { rare) }\end{array}$ & & $\begin{array}{l}\text { 2. Severe } \\
\text { conditions that } \\
\text { being able to be } \\
\text { confirmed by } \\
\text { other tests. } \\
\text { Treatments or } \\
\text { interventions } \\
\text { are available }\end{array}$ & & $\begin{array}{l}\text { 3. lead to } \\
\text { treatment or } \\
\text { interruption }\end{array}$ \\
\hline \multirow[t]{3}{*}{$\begin{array}{l}\text { Information } \\
\text { from test }\end{array}$} & \multirow{2}{*}{$\begin{array}{l}\text { 1. As much as } \\
\text { possible on this } \\
\text { risk/probability } \\
\text { that baby might } \\
\text { have genetic } \\
\text { problems }\end{array}$} & \multirow[t]{3}{*}{$\begin{array}{l}\text { Information } \\
\text { from test }\end{array}$} & \multirow{2}{*}{$\begin{array}{l}\text { 1. Reliable and } \\
\text { comprehensive } \\
\text { information; } \\
\text { Results are } \\
\text { easily } \\
\text { interpreted }\end{array}$} & \multirow[t]{3}{*}{$\begin{array}{l}\text { Information } \\
\text { from test } \\
\text { result }\end{array}$} & $\begin{array}{l}1 . \\
\text { Information } \\
\text { on risk of } \\
\text { disability }\end{array}$ \\
\hline & & & & & $\begin{array}{l}\text { 2. Medical } \\
\text { implications }\end{array}$ \\
\hline & $\begin{array}{l}\text { 2. Simple } \\
\text { information }\end{array}$ & & $\begin{array}{l}\text { 2. Simple } \\
\text { information. } \\
\text { Difficult to } \\
\text { make prognosis }\end{array}$ & & $\begin{array}{l}\text { 3. Social } \\
\text { implications }\end{array}$ \\
\hline \multirow[t]{8}{*}{$\begin{array}{l}\text { Test } \\
\text { performance }\end{array}$} & \multirow[t]{2}{*}{$\begin{array}{l}\text { 1. Not consider } \\
\text { a test with false } \\
\text { positive rate } \\
\text { higher than } 5 \%\end{array}$} & \multirow[t]{8}{*}{$\begin{array}{l}\text { Test } \\
\text { performance }\end{array}$} & \multirow[t]{4}{*}{$\begin{array}{l}\text { 1. Low false } \\
\text { positive and } \\
\text { false negative } \\
\text { rates }\end{array}$} & \multirow[t]{4}{*}{$\begin{array}{l}\text { Test } \\
\text { sensibility }\end{array}$} & $\begin{array}{l}\text { 1. Equal or } \\
\text { less than } \\
75 \%\end{array}$ \\
\hline & & & & & 2. $76 \%-85 \%$ \\
\hline & \multirow{2}{*}{$\begin{array}{l}\text { 2. Detection } \\
\text { rate: } 50 \%-95 \%\end{array}$} & & & & 3. $86-95 \%$ \\
\hline & & & & & $\begin{array}{l}\text { 4. Equal or } \\
\text { above } 96 \%\end{array}$ \\
\hline & \multirow[t]{2}{*}{$\begin{array}{l}\text { 3. Detection } \\
\text { rate: above 95\% }\end{array}$} & & \multirow{4}{*}{$\begin{array}{l}\text { 2. Higher false } \\
\text { positive rate to } \\
\text { maximize } \\
\text { number of } \\
\text { cases }\end{array}$} & \multirow[t]{4}{*}{$\begin{array}{l}\text { Test } \\
\text { specificity }\end{array}$} & $\begin{array}{l}\text { 1. Equal or } \\
\text { less than } \\
75 \%\end{array}$ \\
\hline & & & & & 2. $76 \%-85 \%$ \\
\hline & \multirow{2}{*}{$\begin{array}{l}\text { 4. Take the test } \\
\text { regardless } \\
\text { detection rate } \\
\text { to reduce risk of } \\
\text { any possible } \\
\text { problems to the } \\
\text { babv }\end{array}$} & & & & 3. $86-95 \%$ \\
\hline & & & & & $\begin{array}{l}\text { 4. Equal or } \\
\text { above } 96 \%\end{array}$ \\
\hline
\end{tabular}




\begin{tabular}{|c|c|c|c|c|c|}
\hline \multicolumn{2}{|c|}{$\begin{array}{l}\text { Preggntant Women. As soon as } \\
\text { result possible }\end{array}$} & \multicolumn{2}{|c|}{ Decision-Makers } & \multirow[t]{3}{*}{$\begin{array}{l}\text { Consensus } \\
\text { results }\end{array}$} & $\begin{array}{l}\text { 1. Before the } \\
\text { third regular }\end{array}$ \\
\hline & 8- 10 weeks & & & & \multirow{2}{*}{$\begin{array}{l}\text { 2. Before the } \\
\text { second (10- } \\
12 \text { week) } \\
\text { regular } \\
\text { pregnancy } \\
\text { visit }\end{array}$} \\
\hline & $\begin{array}{l}\text { 2. After } 10 \\
\text { weeks }\end{array}$ & & & & \\
\hline & & \multirow[t]{2}{*}{$\begin{array}{l}\text { Test } \\
\text { procedure }\end{array}$} & $\begin{array}{l}\text { 1. Test } \\
\text { procedure and } \\
\text { confirmation } \\
\text { tests are simple } \\
\text { and rapid which } \\
\text { are not resulting } \\
\text { in stresses on } \\
\text { women }\end{array}$ & \multirow[t]{2}{*}{$\begin{array}{l}\text { Simplification } \\
\text { of test } \\
\text { procedure }\end{array}$} & 1. simple \\
\hline & & & $\begin{array}{l}\text { 2. Complex test } \\
\text { procedure } \\
\text { causing stress } \\
\text { on women }\end{array}$ & & 2. complex \\
\hline \multirow{4}{*}{$\begin{array}{l}\text { Cost related } \\
\text { to the test }\end{array}$} & $\begin{array}{l}\text { 1. } \$ O \text { (Cost-free } \\
\text { access) }\end{array}$ & \multirow{4}{*}{$\begin{array}{l}\text { Cost related } \\
\text { to the test }\end{array}$} & \multirow{2}{*}{$\begin{array}{l}\text { 1. Affordable } \\
\text { cost accepted } \\
\text { by pregnant } \\
\text { women }\end{array}$} & \multirow{4}{*}{$\begin{array}{l}\text { Cost related } \\
\text { to the test }\end{array}$} & 1. $0 S$ \\
\hline & 2. $\$ 100-\$ 500$ & & & & 2. $100 \$$ \\
\hline & \multirow{2}{*}{$\begin{array}{l}\text { 3. Willing to pay } \\
\text { to have } \\
\text { information of } \\
\text { test regardless } \\
\text { the amount of } \\
\text { money }\end{array}$} & & \multirow[t]{2}{*}{$\begin{array}{l}\text { 2. Reasonable } \\
\text { cost for public } \\
\text { system, not } \\
\text { overcome } \\
\text { threshold }\end{array}$} & & 3. $200 \$$ \\
\hline & & & & & 4. $300 \$$ \\
\hline \multirow[t]{5}{*}{$\begin{array}{l}\text { Test } \\
\text { uncertainty }\end{array}$} & \multirow[t]{2}{*}{$\begin{array}{l}\text { 1. Not consider } \\
\text { a test with low } \\
\text { accuracy rate } \\
\text { of severity }\end{array}$} & \multirow[t]{5}{*}{$\begin{array}{l}\text { Test } \\
\text { uncertainty }\end{array}$} & \multirow{2}{*}{$\begin{array}{l}\text { 1. Not likely to } \\
\text { accept low level } \\
\text { of certainty } \\
\text { regardless } \\
\text { health } \\
\text { outcomes: } \\
\text { physical or } \\
\text { intellectual }\end{array}$} & \multirow[t]{5}{*}{$\begin{array}{l}\text { Test } \\
\text { uncertainty }\end{array}$} & $\begin{array}{l}1 . \\
\text { Regardless } \\
\text { the } \\
\text { uncertainty }\end{array}$ \\
\hline & & & & & $\begin{array}{l}\text { 2. Accept } \\
\text { low } \\
\text { accuracy }\end{array}$ \\
\hline & \multirow{2}{*}{$\begin{array}{l}\text { 2. Take the test } \\
\text { regardless the } \\
\text { uncertainty } \\
\text { level (neither } \\
\text { physical nor } \\
\text { intellectual } \\
\text { problems) }\end{array}$} & & \multirow{3}{*}{$\begin{array}{l}\text { 2. Accept } \\
\text { uncertainty but } \\
\text { depending on } \\
\text { severity of } \\
\text { screened } \\
\text { conditions }\end{array}$} & & $\begin{array}{l}\text { physical } \\
\text { problems }\end{array}$ \\
\hline & & & & & $\begin{array}{l}\text { 3. Not taking } \\
\text { test with the } \\
\text { uncertainties }\end{array}$ \\
\hline & $\begin{array}{l}\text { 3. Prefer a test } \\
\text { with higher } \\
\text { accuracy rate } \\
\text { of intellectual } \\
\text { nrnhlome }\end{array}$ & & & & \\
\hline
\end{tabular}




\section{Pregnant Women}

Decision-Makers

Consensus

Table 3 displays the initial list of ten attributes based on the identification of categories and decision points. Seven attributes ('condition to be screen', 'information provided from test result', 'cost of test', 'test uncertainty', 'test performance', 'test sensibility' and 'test specificity') were built from what was said by both groups of participants. Two attributes were built from what was said by women only ('moment at gestational age to obtain the test result', 'geographical access to the test') and one from what was said by decision-makers only ('test procedure'). Although based on responses provided by a single group, these attributes were retained by the researchers on the basis that they could be of interest to the other group. Yet, this hypothesis would be tested in the next step of the construction of the instrument. 
Table 3

Potential attributes and levels for consultations and focused group discussion

\section{Attributes}

1. Conditions to be screened

2. The test result that is presented to a pregnant woman is about

3. Test performance

1. known

2. uncertain

4. Test sensibility

5. Test specificity

6. Moment at gestational age to obtain the test result

7. Cost related to the test

\section{$1.0 S$}

2. $100 \$$

3. $200 \$$

\section{4. $300 S$}

8. Degree of test result certainty to the severity of the disability

1. the child will have a physical and/or intellectual disability

2. the child could have the disease, but without it resulting in a physical and/or intellectual disability

9. Test procedure

1. simple

2. complex

10. Geographical access to the test
1. in a local health care facility (e.g., CLSC)

Page $14 / 29$ 


\begin{tabular}{|l|l|}
\hline Attributes & Levels \\
\hline 2. the confirmatory test is done in a regional hospital \\
\hline $\begin{array}{l}\text { 3. the confirmatory test can only be done in a hospital } \\
\text { located in a city center }\end{array}$ \\
\hline
\end{tabular}

Attribute selection and framing were based on consultations with two decision-makers and a pregnant woman, and a focus group with one decision-maker (who participated in the in-depth interview and who agreed to participate in future studies) and three pregnant women (who had not participated in the first interviews). The consultations were done by email. Participants to the consultation process proposed to eliminate the two attributes mentioned only by decision-makers, test specificity and test sensibility, since the medical terms might not give much significant meaning to pregnant women and were difficult to understand by a layperson. This was confirmed by the focus group discussion.

The consultations and the focus group discussion also led to the rewording of some attributes and levels in order to facilitate the comprehension of the questionnaire (for example, 'test procedure' became 'test sufficiency'). The process reduced the questionnaire to eight attributes. Five attributes had two levels and three attributes had three levels. Amongst the attributes, the levels of 'cost related to the test' was built based on what women said about how much out-of-pocket money they were ready to give for the test, as well as the real cost of the NIPS test presently offered in the public health care system. Details are provided in Table 4. 
Table 4

List of attribute and attribute levels for the pilot project

Attributes Levels Explication

1. Conditions to be screened
1. can be treated or lead to a termination of pregnancy

2. can be treated or lead to termination of pregnancy and should not be rare
A test can detect as many conditions as possible, provided that in case of a positive result, medical intervention is then possible.

A rare disease is defined as a condition that affects less than one in 200,000 individuals. This test would therefore make it possible to detect diseases that are rarer than Down syndrome, which affects 300 children out of 200,000 births.

\section{Test}

1. known

performance (degree of accuracy of the test result)
In a few cases, the result of a screening test is incorrect. When the percentage of the error is known, the mother can be told what the probability is, that a second test, called a confirmatory test, which is rarely wrong, will confirms or reject the first test result.

2. uncertain

In a few cases, the result of a screening test is incorrect. When the percentage of error is uncertain, the probability that a second, confirmatory test, which is rarely wrong, will confirm or invalidate the first test result cannot be specified. An uncertain result is common for rare diseases

3. Moment at gestational age to obtain the test result

\section{Degree of} test result certainty to the severity of the disability

\section{1. before or at the third prenatal visit}

2. before or at the second prenatal visit

1. the child is certain to have a severe physical and/or intellectual disability that will affect the child's quality of life

2. the child may have the disease. However, having the disease does not necessarily mean that the child will have a severe physical and/or intellectual disability

5. Test sufficiency
1. a positive result can be confirmed during regular prenatal visits

2. a positive result may require confirmation by tests that are not offered during regular visits
The result is communicated at the latest during the third prenatal visit, around the 24th week of pregnancy

The result is communicated at the latest, during the second prenatal visit, around the 18th week

The result may detect a physical or intellectual problem that will lead to a severe disability that will affect the child's quality of life

The result can detect an intellectual or physical problem but does not indicate the severity of the disability.
Screening interventions are offered to all women during a regular pregnancy visit

Screening interventions may require additional interventions, such as additional visits or specific tests like amniocentesis 


\begin{tabular}{|c|c|c|}
\hline Attributes & Levels & Explication \\
\hline \multirow{3}{*}{$\begin{array}{l}6 . \text { The test } \\
\text { result that is } \\
\text { presented to } \\
\text { a pregnant } \\
\text { woman is } \\
\text { about }\end{array}$} & 1. the risk of disability & $\begin{array}{l}\text { The information is about the possibility that the } \\
\text { child may have a disability }\end{array}$ \\
\hline & $\begin{array}{l}\text { 2. the risk of disability and } \\
\text { its medical implications }\end{array}$ & $\begin{array}{l}\text { The information is about the possibility that the } \\
\text { child may have a disability and the medical } \\
\text { consequences of the disability which may require } \\
\text { treatment. }\end{array}$ \\
\hline & $\begin{array}{l}\text { 3. the risk of disability, its } \\
\text { medical and social } \\
\text { implications }\end{array}$ & $\begin{array}{l}\text { The information is about the possibility that the } \\
\text { child may have a disability, the medical } \\
\text { consequences of the disability, and the social impact } \\
\text { of the disability on the life of the child and family. }\end{array}$ \\
\hline \multirow{3}{*}{$\begin{array}{l}7 . \\
\text { Geographical } \\
\text { access to the } \\
\text { test }\end{array}$} & $\begin{array}{l}\text { 1. all screening services are } \\
\text { provided at a local health } \\
\text { facility (e.g., CLSC) }\end{array}$ & $\begin{array}{l}\text { Screening can be done at a facility near the pregnant } \\
\text { woman's residence }\end{array}$ \\
\hline & $\begin{array}{l}\text { 2. if the test is positive, } \\
\text { confirmatory testing is done } \\
\text { at a regional hospital }\end{array}$ & $\begin{array}{l}\text { Full testing (screening and confirmatory testing) } \\
\text { may require a pregnant woman to go to the local } \\
\text { referral hospital }\end{array}$ \\
\hline & $\begin{array}{l}\text { 3. if the test is positive, } \\
\text { confirmatory testing can } \\
\text { only be done in a hospital } \\
\text { located in a big city }\end{array}$ & $\begin{array}{l}\text { Full testing (screening and confirmatory testing) } \\
\text { may require a pregnant woman to go to a hospital in } \\
\text { an urban center }\end{array}$ \\
\hline \multirow{3}{*}{$\begin{array}{l}\text { 8. Cost } \\
\text { related to the } \\
\text { test }\end{array}$} & $1.0 S$ & \\
\hline & 2. $150 S$ & \\
\hline & 3. $300 \$$ & \\
\hline
\end{tabular}

\section{Stage 2 and 3: Experimental design, construction of tasks and the DCE survey design}

Figure 2 illustrates an example of a choice task in the DCE survey. An example of the full survey is available on request.

\section{Stage 4: Results of the pilot-test}

The pilot project conducted with 33 pregnant women (aged from 19 to 37 years) was completed within 10 weeks (from 5th July to 12th September 2021). Over a total of 115 invitations sent, 68 women agreed to participate in the study. Among which, 36 full responses were received (53\% response rate).

The pilot project revealed that it took an average of 11 minutes for participants to complete the questionnaire (2 minutes in minimum; 49 minutes in maximum).

Table 5 shows that the 'test performance' attribute was the most contributive to the choices made, followed by 'moment in gestational age to obtain test result', 'test sufficiency', 'costs', 'test uncertainty', and 'information provided from test result' ( $p$-values $<0.05$ ). Two other attributes, 'condition to be 
screened' and 'geographical access to the test', are the least influential to the choice made ( $p$-values at 0.2218 and 0.3247 respectively). Furthermore, the analysis also revealed which attribute levels were preferred by pregnant women. These results allowed us to form a choice task containing a dominant option for the full-scale DCE study that will be used to evaluate if answers given are random or wellthought. 
Table 5

Conditional analysis of effects

\begin{tabular}{|c|c|c|c|c|c|c|c|}
\hline Attributes & Levels & DF & Coefficient & $\begin{array}{l}\text { Standard } \\
\text { Error }\end{array}$ & $\begin{array}{l}\text { Wald } \\
\text { Chi- } \\
\text { Square }\end{array}$ & $\mathrm{Pr}>\mathrm{ChiSq}$ & $\begin{array}{l}\text { Entry } \\
\text { order in } \\
\text { the } \\
\text { stepwise } \\
\text { selection }\end{array}$ \\
\hline \multirow{2}{*}{$\begin{array}{l}\text { Conditions to be } \\
\text { screened }\end{array}$} & 1 & 1 & -0.3354 & 0.2745 & 1.4927 & 0.2218 & 7 \\
\hline & 2 & 0 & 0 & . & . & . & \\
\hline \multirow{2}{*}{$\begin{array}{l}\text { Test performance } \\
\text { (degree of accuracy } \\
\text { of the test result) }\end{array}$} & 1 & 0 & 0 & . & . & . & 1 \\
\hline & 2 & 1 & -1.3176 & 0.2776 & 22.5266 & $<.0001$ & \\
\hline \multirow{2}{*}{$\begin{array}{l}\text { Moment at } \\
\text { gestational age to } \\
\text { obtain the test result }\end{array}$} & 1 & 1 & -0.7890 & 0.2674 & 8.7046 & 0.0032 & 2 \\
\hline & 2 & 0 & 0 & . & . & & \\
\hline \multirow{2}{*}{$\begin{array}{l}\text { Degree of test result } \\
\text { certainty to the } \\
\text { severity of the } \\
\text { disability }\end{array}$} & 1 & 0 & 0 & . & . & . & 5 \\
\hline & 2 & 1 & -0.8860 & 0.2740 & 10.4550 & 0.0012 & \\
\hline \multirow[t]{2}{*}{ Test sufficiency } & 1 & 0 & 0 & . & . & . & 3 \\
\hline & 2 & 1 & -0.6799 & 0.2586 & 6.9098 & 0.0086 & \\
\hline \multirow{3}{*}{$\begin{array}{l}\text { The test result that is } \\
\text { presented to a } \\
\text { pregnant woman is } \\
\text { about }\end{array}$} & 1 & 1 & -1.0263 & 0.3525 & 8.4742 & 0.0036 & 6 \\
\hline & 2 & 1 & -0.3915 & 0.3375 & 1.3459 & 0.2460 & \\
\hline & 3 & 0 & 0 & . & & . & \\
\hline \multirow{3}{*}{$\begin{array}{l}\text { Geographical access } \\
\text { to the test }\end{array}$} & 1 & 0 & 0 & . & & . & 8 \\
\hline & 2 & 1 & -0856 & 0.3198 & 0.0716 & 0.7891 & \\
\hline & 3 & 1 & 0.3854 & 0.3291 & 1.3717 & 0.2451 & \\
\hline \multirow{2}{*}{$\begin{array}{l}\text { Cost related to the } \\
\text { test }\end{array}$} & 1 & 0 & 0 & . & . & . & 4 \\
\hline & 2 & 1 & -0.4190 & 0.3430 & 1.4927 & 0.2218 & \\
\hline
\end{tabular}


The conditional logit model found most attributes to be statistically significantly associated with the choice ( $p$ value $<0.05$ ), except 'geographical access to the test' and 'conditions to be screened' attributes ( $p$ values at 0.3247 and 0.2218 respectively). However, because the predefined threshold for retaining an attribute was fixed at $25 \%$ (36), only the 'geographical access to the test' attribute was excluded.

Statistical analyses did not suggest bringing modifications to the attribute levels. However, researchers decided to extend the maximum of cost paid by users of the test of $\$ 1000$ with a $\$ 200$ increment (6 level attribute) to reflect the real amount that women might have to pay for detecting some anomalies not presently listed in a prenatal screening program, with the NIPS test.

\section{Stage 5: Refinement and full-scale DCE survey}

The pilot project results were used to finalize the questionnaire for the full-scale DCE survey.

This final DCE questionnaire contains seven attributes ( 5 attributes with 2 levels, one attribute with 3 levels and one attribute with 6 levels) (Table 6). 
Table 6

Final list of attributes and levels for full-scale DCE

Attributes Levels

1. Conditions to be screened

2. Test performance (degree of accuracy of the test result)

3. Moment at gestational age to obtain the test result

4. Degree of test result certainty to the severity of the disability

5. Test sufficiency presented to a pregnant woman is about
1. can be treated or lead to a termination of pregnancy

2. can be treated or lead to termination of pregnancy and should not be rare

\section{1. known}

2. uncertain

1. before or at the third prenatal visit

2. before or at the second prenatal visit

1. the child is certain to have a severe physical and/or intellectual disability that will affect the child's quality of life

2. the child may have the disease. However, having the disease does not necessarily mean that the child will have a severe physical and/or intellectual disability

1. a positive result can be confirmed during regular prenatal visits

2. a positive result may require confirmation by tests that are not offered during regular visits

1. the risk of disability

2. the risk of disability and its medical implications

3. the risk of disability, its medical and social implications

7. Cost related to the test

$1.0 \$$

2. $200 \$$

3. $400 \$$

4. $600 \$$

5. $800 \$$

6. $1000 \$$

\section{Discussion}

The work presented in this study concerns the construction of a DCE instrument addressing the issue of adding a test to a prenatal screening program, which can be administered to both patients and decisionmakers. Having an instrument built on the preoccupation of both groups available allows researchers to compare the desirability levels for a new test from both sides. It allows the decision-making process to 
include in the data used to support their decision, comparable information provided by groups that can have different preoccupations, but whose concerns, from a social perspective, are equally relevant.

The instrument shows similarities in its attributes with other DCE instruments built for use in studies on prenatal screening of the fetus (37-40). All instruments have attributes related to the level of information provided by the test results, to the time, in gestational age, to receive the results of a screening test, and to the test sufficiency, i.e., the impact of the test on the need of further invasive/non-invasive procedures to confirm a screening result. All instruments have a 'test performance' attribute, presented sometimes in different terms as 'detection rate', 'accuracy rate' (37-40). Unsurprisingly, this concern was also shared by decision-makers involved in the construction of our instrument but described in terms of 'false-negative and 'false-positive' rates.

However, two dimensions that are present in our DCE instrument, are not found in other DCE instruments: one regarding which conditions that should be screened and one regarding which certainty level of the test result regarding the severity of a disability could be accepted. The reason for the discrepancy is probably due to the fact that other DCE instruments focus on the use of tests to screen for common chromosomal anomalies, for which the performance of the test is high. Our instrument targets potential chromosomal conditions that are not screened for but could be added to a screening program. The performance of the detection test for these conditions tends to be lower. These conditions tend also to lead to a wide range of phenotypes, hence of the severity of disability $(37,39,41-44)$.

Moreover, the construction of the DCE instrument shows that a consensus can be reached on a final version, even if some attributes have been proposed by only one group. This probably reflects the respect and interest of all participants for preoccupation with some attributes that were of little concern to them before the study, but whose evocation has aroused an interest. To our knowledge, only one DCE instrument, in the field of pharmacy subsidy decisions, might have been applied to both patients and decision-makers (45). Yet, this paper contains some uncertainties whether both the public and health decision-maker/experts were effectively involved in the identification of the questionnaire attributes. This paper doesn't provide information regarding if and how a consensus on the DCE instrument attributes between both groups have been looked for $(45,46)$.

\section{Conclusion}

This study shows that it is possible to develop a DCE instrument to elicit values for an intervention that reflects the demand and the supply sides of the health care systems. By expanding the range of stakeholders involved in the valorization of an intervention, such an instrument might contribute to the efforts deployed to address the societal value of an innovation. Yet, a DCE study is resource-consuming and might give results that are difficult to explain to the target audience. The acceptability of this approach is therefore an issue. Research on these added values of DCE in the world of economic evaluation is still warranted. 


\section{Abbreviations}

HEE: Health Economic Evaluations; CBA: Cost-Benefit Analyses; cfDNA: cell-free Fetal DNA; CHUL: Centre Hospitalier de l'Université Laval; CUA: Cost-Utility Analyses; DCE: Discrete Choice Experiment; HTA: Health Technology Assessment; INESSS: Institut National d'Excellence en Santé et Services Sociaux; ISPOR: International Society for Pharmacoeconomics and Outcomes Research; NIPS: Non-Invasive Prenatal Screening; QALYs: Quality-Adjusted Life-years; WTP: Willingness-To-Pay

\section{Declarations}

\section{Ethics approval and consent to participate}

Ethics approval for this study was obtained from Comité d'éthique de la recherche du CHU de QuébecUniversité Laval (project 2020-4877), and permission was granted to enroll participants at the CHUL hospital in Quebec City (Canada).

\section{Consent to publication}

Not applicable.

\section{Availability of data and materials}

Not applicable.

\section{Competing interests}

The authors declare that they have no competing interests.

\section{Funding}

The present study was part of the PEGASUS2 project funded by Genome Canada, the Canadian Institutes for Health Research, Genome Québec, Genome BC, Genome Alberta, the Québec Ministère de l'Enseignement supérieur, de la recherche, de la science et de la technologie, the Fonds de recherche Québec - Santé, la Fondation de l'Université Laval and the Centre de recherche du CHU de Québec. Jason $\mathrm{R}$ Guertin is a FRQS Research Scholar Junior 1 (Award \#266460).

\section{Authors' contributions}

HMN conceptualized the scope and aims of the study, developed the method, collected data, conducted analyses, and drafted the manuscript. CL collected and analyzed the data. MB developed questionnaires on online survey platform and provided technical aid on respondent recruitments. JRG and LN contributed to the ongoing development of the manuscript. BS collected and analyzed data of the systematic review of literature. DR supervised all stages of the study. All named authors have approved the manuscript. 


\section{Acknowledgements}

We would like to express our thanks to Gaétan Daigle for his valuable contribution in the data statistical analyses. We are also grateful to Sylvie Tapp and Josée Mailhot at the CHU de Québec-Université Laval for their excellent administrative support throughout the data collection.

\section{References}

1. Beierle TC, Cayford Jerry, Cayford J. Democracy in practice: public participation in environmental decisions. Washington, Dc: Resources for the Future; 2002.

2. Graham KA, Phillips SD. Making Public Participation more Effective: Issues for Local Government. In: Graham, Katherine A et Phillips, Susan D (eds) Citizen engagement: lessons in participation from local government. Toronto: Institute of Public Administration of Canada; 1998. p. 1-24.

3. Nelimarkka M. A Review of Research on Participation in Democratic Decision-Making Presented at SIGCHI Conferences. Toward an Improved Trading Zone Between Political Science and $\mathrm{HCl}$. Proc ACM Hum-Comput Interact [Internet]. 2019 Nov 7 [cited 2021 Jun 22];3(CSCW):1-29. Available from: https://dl.acm.org/doi/10.1145/3359241

4. Richardson J, Schlander M. Health technology assessment (HTA) and economic evaluation: efficiency or fairness first. J Mark Access Health Policy [Internet]. 2019 Jan 1 [cited 2021 Oct 28];7(1):1557981. Available from: https://www.tandfonline.com/doi/full/10.1080/20016689.2018.1557981

5. Kandiyali R, Hawton A, Cabral C, Mytton J, Shilling V, Morris C, et al. Working with Patients and Members of the Public: Informing Health Economics in Child Health Research. PharmacoEconomics - Open [Internet]. 2019 Jun [cited 2021 Jun 23];3(2):133-41. Available from: http://link.springer.com/10.1007/s41669-018-0099-7

6. O'Shea E, Ogbebor F, Queally M, Murphy E. Knowledge of public patient involvement among health economists in Ireland: a baseline audit. HRB Open Res [Internet]. 2019 Feb 1 [cited 2021 Jun 23];2:4. Available from: https://hrbopenresearch.org/articles/2-4/v1

7. Weeks L, Polisena J, Scott AM, Holtorf A-P, Staniszewska S, Facey K. Evaluation of Patient and Public Involvement Initiatives in Health Technology Assessment: A Survey of International Agencies. Int J Technol Assess Health Care. 2017 Jan;33(6):715-23.

8. Stamuli E. Health outcomes in economic evaluation: who should value health? Br Med Bull [Internet]. 2011 Mar 1 [cited 2021 Oct 26];97(1):197-210. Available from: https://academic.oup.com/bmb/article-lookup/doi/10.1093/bmb/ldr001

9. Mooney GH. Cost-benefit analysis and medical ethics. J Med Ethics [Internet]. 1980 Dec 1 [cited 2021 Nov 4];6(4):177-9. Available from: https://jme.bmj.com/lookup/doi/10.1136/jme.6.4.177

10. Torrance GW. Measurement of health state utilities for economic appraisal: a review. J Health Econ. 1986;5(1):30. 
11. Drummond M, Sculpher MJ, Claxton K, Stoddart GL, Torrance GW, Askews \& Holts Library Services. Methods for the economic evaluation of health care programmes [Internet]. Fourth edition. / Fourth edition. Oxford: Oxford University Press; 2015. (Oxford medical publications). Available from: https://search.ebscohost.com/login.aspx?

direct=true\&scope $=$ site $\& d b=$ nlebk $\& d b=$ nlabk\&AN $=1259911$

12. Nuijten MJC, Dubois DJ. Cost-Utility Analysis: Current Methodological Issues and Future Perspectives. Front Pharmacol [Internet]. 2011 [cited 2021 Nov 4];2. Available from: http://journal.frontiersin.org/article/10.3389/fphar.2011.00029/abstract

13. Payakachat N, Murawski MM, Summers KH. Health utility and economic analysis: theoretical and practical issues. Expert Rev Pharmacoecon Outcomes Res [Internet]. 2009 Aug [cited 2021 Nov 4];9(4):289-92. Available from: http://www.tandfonline.com/doi/full/10.1586/erp.09.36

14. Fauteux V, Poder T. État des lieux sur les méthodes d'élicitation du QALY. CybelePress; 2017.

15. Hulst S, Brouwer W, Mol B, Akker-van Marle M. Challenges in economic evaluations in obstetric care: a scoping review and expert opinion. BJOG Int J Obstet Gynaecol [Internet]. 2020 Oct [cited 2021 Oct 28];127(11):1399-407. Available from: https://onlinelibrary.wiley.com/doi/10.1111/14710528.16243

16. Bianchi DW, Chiu RWK. Sequencing of Circulating Cell-free DNA during Pregnancy. N Engl J Med [Internet]. 2018 Aug 2 [cited 2019 Jul 4];379(5):464-73. Available from: http://www.nejm.org/doi/10.1056/NEJMra1705345

17. Thomas J, Harraway J, Kirchhoffer D. Non-invasive prenatal testing: clinical utility and ethical concerns about recent advances. Med J Aust [Internet]. 2021 Mar [cited 2021 May 7];214(4):168. Available from: https://onlinelibrary.wiley.com/doi/10.5694/mja2.50928

18. Zaami S, Orrico A, Signore F, Cavaliere AF, Mazzi M, Marinelli E. Ethical, Legal and Social Issues (ELSI) Associated with Non-Invasive Prenatal Testing: Reflections on the Evolution of Prenatal Diagnosis and Procreative Choices. Genes [Internet]. 2021 Jan 30 [cited 2021 Mar 2];12(2):204. Available from: https://www.mdpi.com/2073-4425/12/2/204

19. Lancsar E, Louviere J. Conducting discrete choice experiments to inform healthcare decision making: A user's guide. PharmacoEconomics [Internet]. 2008 [cited 2019 Feb 18];26(8):661-77. Available from: http://link.springer.com/10.2165/00019053-200826080-00004

20. Vass CM, Georgsson S, Ulph F, Payne K. Preferences for aspects of antenatal and newborn screening: a systematic review. BMC Pregnancy Childbirth [Internet]. 2019 Dec [cited 2019 Aug 15];19(1):131. Available from: https://bmcpregnancychildbirth.biomedcentral.com/articles/10.1186/s12884-019-2278-7

21. Krabbe PFM, Jabrayilov R, Detzel P, Dainelli L, Vermeulen KM, van Asselt ADI. A two-step procedure to generate utilities for the Infant health-related Quality of life Instrument (IQI). Tian J, editor. PLOS ONE [Internet]. 2020 Apr 3 [cited 2021 Nov 15];15(4):e0230852. Available from: https://dx.plos.org/10.1371/journal.pone.0230852 
22. Bridges JFP, Hauber AB, Marshall D, Lloyd A, Prosser LA, Regier DA, et al. Conjoint analysis applications in health - a checklist: a report of the ISPOR good research practices for conjoint analysis task force. Value Health [Internet]. 2011 Jun [cited 2019 Feb 17];14(4):403-13. Available from: https://linkinghub.elsevier.com/retrieve/pii/S1098301510000835

23. Ryan M, Bate A, Eastmond CJ, Ludbrook A. Use of discrete choice experiments to elicit preferences. Qual Saf Health Care [Internet]. 2001 Sep 1 [cited 2019 Feb 13];10(Supplement 1):i55-60. Available from: http://qualitysafety.bmj.com/lookup/doi/10.1136/qhc.0100055

24. Vass C, Rigby D, Payne K. The Role of Qualitative Research Methods in Discrete Choice Experiments: A Systematic Review and Survey of Authors. Med Decis Making [Internet]. 2017 Apr [cited 2019 Apr 29];37(3):298-313. Available from: http://journals.sagepub.com/doi/10.1177/0272989X16683934

25. Fortin M-F, Gagnon J. Fondements et étapes du processus de recherche: méthodes quantitatives et qualitatives. 3e édition. Montréal: Chenelière éducation; 2015.

26. Pope C. Qualitative research in health care: Analysing qualitative data. BMJ [Internet]. 2000 Jan 8 [cited 2021 Aug 3];320(7227):114-6. Available from:

https://www.bmj.com/lookup/doi/10.1136/bmj.320.7227.114

27. Lincoln YS, Guba EG, Guba EG. Naturalistic inquiry. Beverly Hills, Calif.: Sage; 1985.

28. Ryan M, Gerard K, Amaya-Amaya M, editors. Using discrete choice experiments to value health and health care. Dordrecht: Springer; 2008. 254 p. (The economics of non-market goods and resources).

29. WHO. How to conduct a discrete choice experiment for health workforce recruitment and retention in remote and rural areas: a user guide with case studies [Internet]. 2012 [cited 2019 Jun 20] p. 94. Available from: https://www.who.int/hrh/resources/dceguide/en/

30. de Bekker-Grob EW, Ryan M, Gerard K. Discrete choice experiments in health economics: a review of the literature. Health Econ [Internet]. 2012 Feb [cited 2019 Feb 18];21(2):145-72. Available from: http://doi.wiley.com/10.1002/hec.1697

31. de Bekker-Grob EW, Hol L, Donkers B, van Dam L, Habbema JDF, van Leerdam ME, et al. Labeled versus Unlabeled Discrete Choice Experiments in Health Economics: An Application to Colorectal Cancer Screening. Value Health [Internet]. 2010 Mar [cited 2021 Aug 16];13(2):315-23. Available from: https://linkinghub.elsevier.com/retrieve/pii/S1098301510603786

32. Veldwijk J, Lambooij MS, de Bekker-Grob EW, Smit HA, de Wit GA. The Effect of Including an Opt-Out Option in Discrete Choice Experiments. Cameron DW, editor. PLoS ONE [Internet]. 2014 Nov 3 [cited 2021 Aug 16];9(11):e111805. Available from: https://dx.plos.org/10.1371/journal.pone.0111805

33. Street DJ, Burgess L. Optimal stated preference choice experiments when all choice sets contain a specific option. Stat Methodol [Internet]. 2004 Dec [cited 2021 Nov 16];1(1-2):37-45. Available from: https://linkinghub.elsevier.com/retrieve/pii/S1572312704000048

34. Burgess L, Street DJ. Optimal designs for choice experiments with asymmetric attributes. J Stat Plan Inference [Internet]. 2005 Sep [cited 2021 Nov 16];134(1):288-301. Available from: https://linkinghub.elsevier.com/retrieve/pii/S0378375804001892 
35. Pukelsheim F. Optimal design of experiments [Internet]. Classic ed. Philadelphia, Pa.: Society for Industrial and Applied Mathematics (SIAM); 2006. (Classics in applied mathematics; 50). Available from: http://epubs.siam.org/ebooks/siam/classics_in_applied_mathematics/cl50

36. Hosmer DW, Lemeshow S, Sturdivant RX. Applied logistic regression. Third edition. Hoboken, New Jersey: Wiley; 2013. 91 p. (Wiley series in probability and statistics).

37. Barrett A, Advani H, Chitty L, Su L, Biswas A, Tan W, et al. Evaluation of preferences of women and healthcare professionals in Singapore for implementation of noninvasive prenatal testing for Down syndrome. Singapore Med J [Internet]. 2017 Jun [cited 2019 Feb 8];58(6):298-310. Available from: http://www.smj.org.sg/article/evaluation-preferences-women-and-healthcare-professionalssingapore-implementation

38. Beulen L, Grutters JPC, Faas BHW, Feenstra I, Groenewoud H, van Vugt JMG, et al. Women's and healthcare professionals' preferences for prenatal testing: a discrete choice experiment: Preferences for prenatal testing: a discrete choice experiment. Prenat Diagn [Internet]. 2015 Jun [cited 2019 Feb 8];35(6):549-57. Available from: http://doi.wiley.com/10.1002/pd.4571

39. Hill M, Fisher J, Chitty LS, Morris S. Women's and health professionals' preferences for prenatal tests for Down syndrome: a discrete choice experiment to contrast noninvasive prenatal diagnosis with current invasive tests. Genet Med [Internet]. 2012 Nov [cited 2019 Feb 8];14(11):905-13. Available from: http://www.nature.com/articles/gim201268

40. Hill M, Twiss P, Verhoef TI, Drury S, McKay F, Mason S, et al. Non-invasive prenatal diagnosis for cystic fibrosis: detection of paternal mutations, exploration of patient preferences and cost analysis: Non-invasive prenatal diagnosis for cystic fibrosis. Prenat Diagn [Internet]. 2015 Oct [cited 2019 Feb 8];35(10):950-8. Available from: http://doi.wiley.com/10.1002/pd.4585

41. Hill M, Suri R, Nash E, Morris S, Chitty L. Preferences for Prenatal Tests for Cystic Fibrosis: A Discrete Choice Experiment to Compare the Views of Adult Patients, Carriers of Cystic Fibrosis and Health Professionals. J Clin Med [Internet]. 2014 Feb 14 [cited 2019 Feb 8];3(1):176-90. Available from: http://www.mdpi.com/2077-0383/3/1/176

42. Hill M, Johnson J-A, Langlois S, Lee H, Winsor S, Dineley B, et al. Preferences for prenatal tests for Down syndrome: an international comparison of the views of pregnant women and health professionals. Eur J Hum Genet [Internet]. 2016 Jul [cited 2019 Feb 8];24(7):968-75. Available from: http://www.nature.com/doifinder/10.1038/ejhg.2015.249

43. Lund ICB, Becher N, Petersen OB, Hill M, Chitty L, Vogel I. Preferences for prenatal testing among pregnant women, partners and health professionals. Dan Med J. 2018 May;65(5):A5486.

44. Mohammadi T, Zhang W, Sou J, Langlois S, Munro S, Anis AH. A Hierarchical Bayes Approach to Modeling Heterogeneity in Discrete Choice Experiments: An Application to Public Preferences for Prenatal Screening. Patient - Patient-Centered Outcomes Res [Internet]. 2020 Apr [cited 2021 Oct 13];13(2):211-23. Available from: http://link.springer.com/10.1007/s40271-019-00402-w

45. Afsharmanesh G, Rahimi F, Zarei L, Peiravian F, Mehralian G. Public and decision-maker stated preferences for pharmaceutical subsidy decisions in Iran: an application of the discrete choice 
experiment. J Pharm Policy Pract [Internet]. 2021 Dec [cited 2021 Nov 10];14(1):74. Available from: https://joppp.biomedcentral.com/articles/10.1186/s40545-021-00365-0

46. Afsharmanesh G, Mehralian G, Peiravian F. Attributes Development for Pharmaceutical

Subsidization: A Qualitative Study. Iran J Pharm Res [Internet]. 2020 Feb [cited 2021 Nov 10];19(1). Available from: https://doi.org/10.22037/ijpr.2019.15507.13136

\section{Figures}

\section{Stage 1: Attribute development}

Attribute identification using mixed method involving target population: review of literature, qualitative method Attribute and level selection and framing using qualitative methods throughout iter ative process: stakeholder consultation; focus group discussion

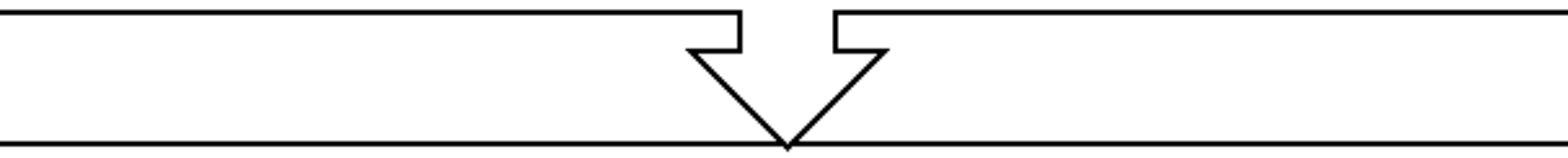

Stage 2: Experimental design and construction of task

Experimental design: fractional factorial using a multinomial logit model with main effects, d-optimizing efficiency

Excluding one dominant choice task: 8 choice tasks for each pregnant woman; 7 choice tasks for each decision-maker

Tasks: paired choices, unlabelled with opt-out option

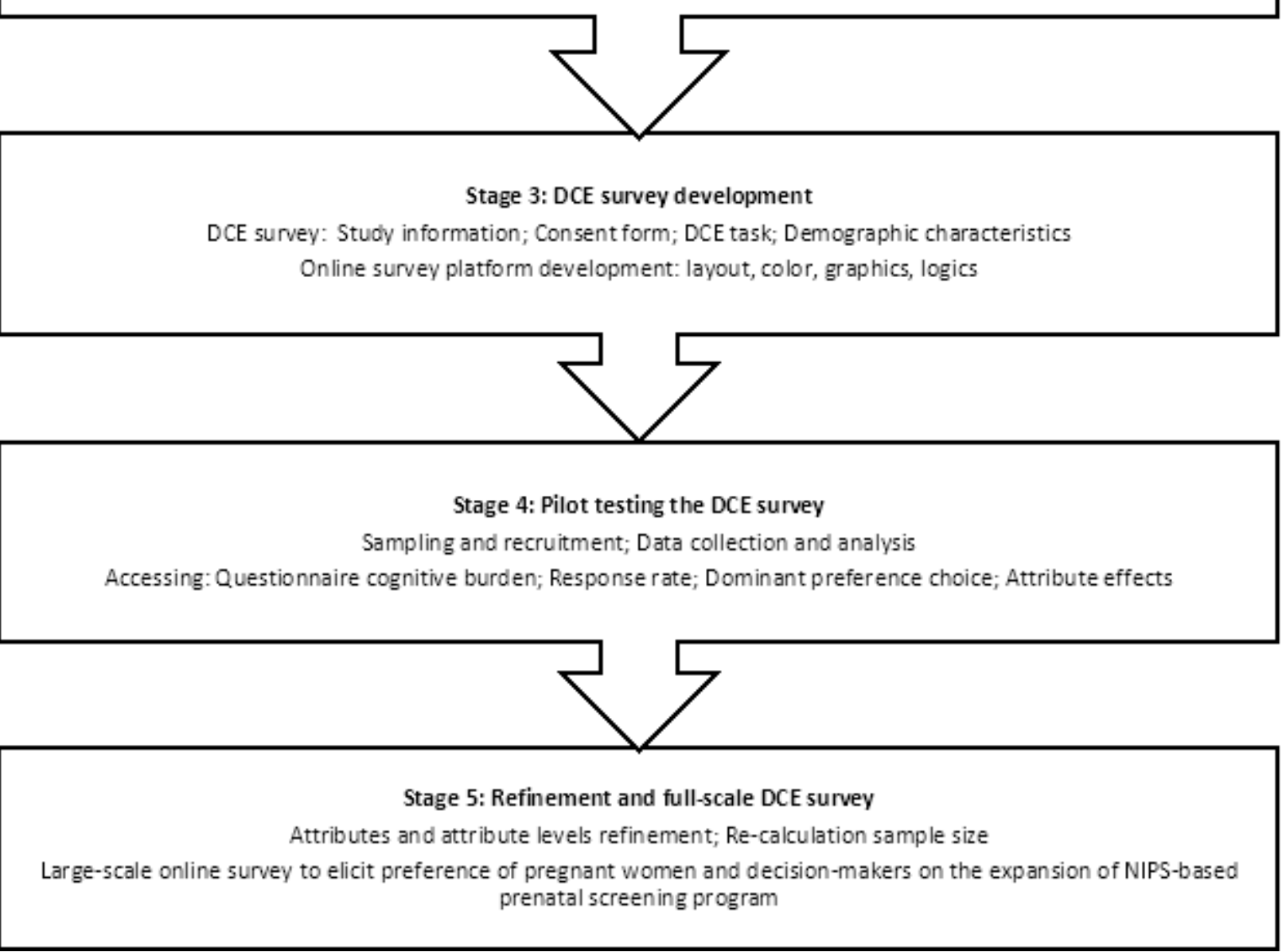

Figure 1 
Section A: Choice of preferred options (1/7)

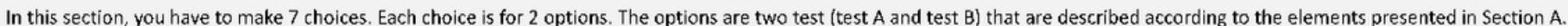
You must choose which of the two tests you prefer. You can also say that you have no preference for these two options.

*A1. What option for the test do you prefer to have (one choice only)?

\begin{tabular}{|c|c|c|}
\hline & Test A & Test B \\
\hline Conditions to be screened & can be treated or lead to a termination of pregnancy & $\begin{array}{l}\text { can be treated or lead to termination of pregnancy and should } \\
\text { not be rare }\end{array}$ \\
\hline Test performance (degree of accuracy of the test result) & known & uncertain \\
\hline Moment at gestational age to obtain the test result & before or at the second prenatal visit & before or at the third prenatal visit \\
\hline Degree of test result certainty to the severity of the disability & $\begin{array}{l}\text { the child may have the disease. However, having the disease } \\
\text { docs not neccssarily mean that the child will have a sevcrc } \\
\text { physical and/or intellectual disability }\end{array}$ & $\begin{array}{l}\text { the child is certain to have a severe physical and/or intellectual } \\
\text { disability that will affect the child's quality of life }\end{array}$ \\
\hline Test sufficiency & a positive result can be confirmed during regular prenatal visits & $\begin{array}{l}\text { a positive result may require confirmation by tests that are not } \\
\text { offered during regular visits }\end{array}$ \\
\hline $\begin{array}{l}\text { The test result that is presented to a pregnant woman is } \\
\text { about }\end{array}$ & the risk of disability & the risk of disability and its medical and social implications \\
\hline Geographical access to the test & $\begin{array}{l}\text { all screcening services are provided at a local health facility } \\
\text { (e.g., CLSC) }\end{array}$ & $\begin{array}{l}\text { if the test is positive, confirmatory testing can only be done in } \\
\text { a hospital located in a big city }\end{array}$ \\
\hline Cost related to the test & $300 \$$ & $150 \$$ \\
\hline
\end{tabular}

Please select an answer below
$\square$ Test A
a Test B
$\square$ None

\section{Figure 2}

Sample of a choice task in the DCE pilot testing project

\section{Supplementary Files}

This is a list of supplementary files associated with this preprint. Click to download.

- Additionalfile1.docx

- Additionalfile2.docx

- Additionalfile3.docx 